\title{
EDITORIAL
}

\section{B cells tell scleroderma fibroblasts to produce collagen}

\author{
Dimitrios Daoussis ${ }^{*}$ and Stamatis-Nick C Liossis \\ See related research by Francois et al., http://arthritis-research.com/content/15/5/R168
}

\begin{abstract}
In fibrosis fibroblasts are activated and overproduce collagen in a process with unknown drivers and equally unknown brakes that recently implicated a novel and surprising player, the B cell. B cells may be crucially involved in fibrosis in several ways: B cells may produce autoantibodies that can directly stimulate fibroblasts; B cells can produce profibrotic cytokines such as IL-6 or transforming growth factor beta; and, finally, B cells could directly stimulate fibroblasts by a contact-dependent mechanism. Recent experimental evidence suggests that B cells can enhance collagen production by fibroblasts, by a contact-dependent mechanism, and therefore are profibrotic ex vivo. These data strengthen the rationale of pursuing B-cell targeting therapies in systemic sclerosis.
\end{abstract}

In fibrosis fibroblasts are activated and overproduce collagen in a process with unknown drivers and equally unknown brakes that recently implicated a novel and surprising player, the $\mathrm{B}$ cell.

In the previous issue of Arthritis Research and Therapy, Francois and colleagues provided experimental evidence of a contact-dependent crosstalk between $B$ cells and fibroblasts; scleroderma fibroblasts exhibit a more than twofold increase in collagen production when co-cultured with B cells compared with when cultured alone [1]. This B-cell-induced collagen production is comparable with the effects of transforming growth factor beta (TGF $\beta$ ), the most potent profibrotic mediator. Enhancement of collagen production was seen when fibroblasts were cocultured with circulating B cells only but not with whole peripheral blood mononuclear cells. Genes encoding collagen I and collagen III were significantly upregulated in the B-cell/fibroblast co-culture system compared with

\footnotetext{
*Correspondence: jimdaoussis@hotmail.com

Department of Internal Medicine, Division of Rheumatology, Patras University Hospital, 26504 Rion, Patras, Greece
}

fibroblasts cultured alone. Importantly, the $\alpha$-smooth muscle actin $\alpha-S M A$ gene that has a key role in the differentiation of fibroblasts into myofibroblasts was also overexpressed.

When the survival factor B-cell activating factor (BAFF) was added along with B-cell receptor-initiated B-cell stimulation in the B-cell/fibroblast co-culture system, a further significant enhancement of collagen production and $\alpha-S M A$ expression was seen; interestingly, the fibroblasts did not express any BAFF receptors. To address the question of whether B cells interact with fibroblasts via direct cell contact or via soluble factors, the authors employed in some experiments a transwell culture system allowing for a free and bidirectional diffusion of soluble factors but prohibiting direct B-cellfibroblast contact. In these transwell experiments the induction of fibroblast collagen production was lost, clearly indicating a contact-dependent mechanism. However, transwells only partially inhibited the effect of BAFF + B-cell receptor stimulation on fibroblasts, indicating that soluble factors also participate in the BAFF scenario. The production of IL-6, chemokine $(\mathrm{C}-\mathrm{C}$ motif) ligand- 2 and TGF $\beta$ was significantly increased in co-cultures and the use of transwells decreased but did not abolish their production. Finally, blocking TGF $\beta$ (but not blocking IL-6) led to a significant inhibition of the effect of B cells plus BAFF on fibroblasts, suggesting a key role for TGF $\beta$.

There are certain issues the reader must take into account to fully interpret this study. The authors initially employed co-cultures of normal B cells with either normal or systemic sclerosis (SSc) skin fibroblasts. Interestingly, the results on collagen production were similar irrespective of the fibroblasts in the co-culture. The authors chose to continue their experiments with fibroblasts obtained from patients with scleroderma skin only, again employing normal B cells in the co-culture system. Francois and colleagues did not employ B cells 


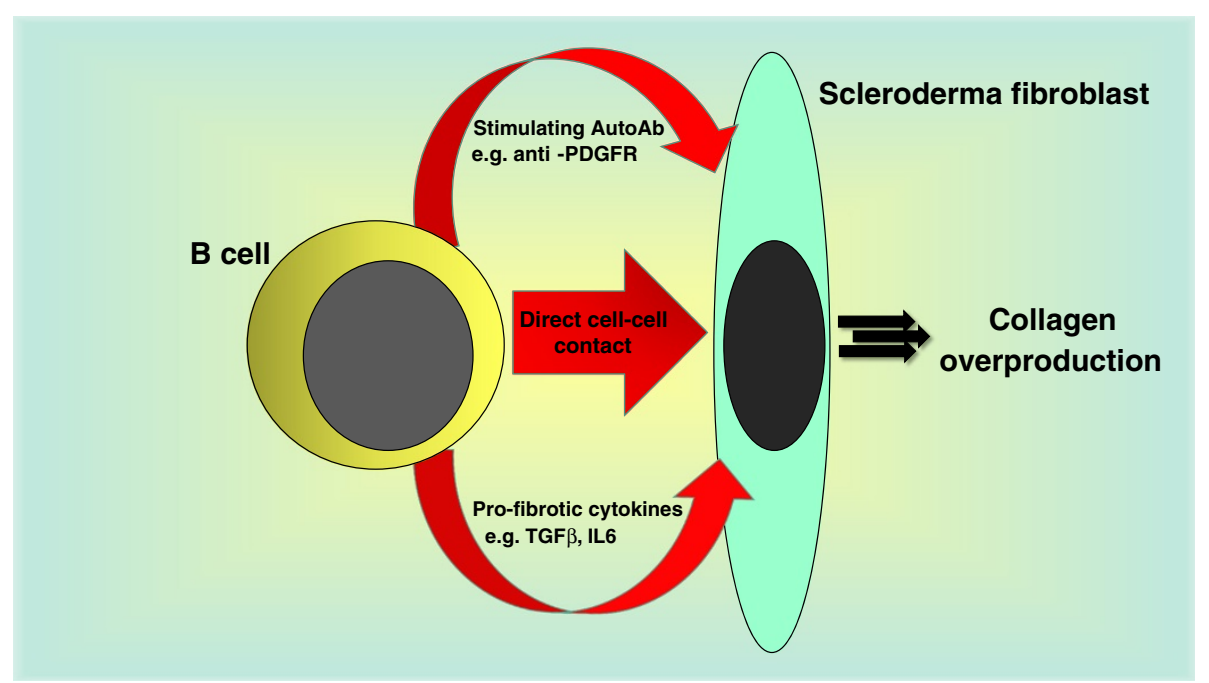

Figure 1 Involvement of B cells in fibrosis. B cells may be crucially involved in fibrosis in several ways: B cells may produce autoantibodies (autoAb) that can directly stimulate fibroblasts; B cells can produce profibrotic cytokines such as IL-6 or transforming growth factor beta (TGF $\beta$ ); and, finally, B cells could directly stimulate fibroblasts by a contact-dependent mechanism. PDGFR, platelet-derived growth factor receptor.

from patients with scleroderma because they speculated that the effect of normal B cells on the fibroblasts was so strong that the activated scleroderma B cell might not be able to produce any stronger effects. This is clearly speculative; an experiment not performed leads to missing potentially valuable data. Therefore, the results of the study by Francois and colleagues could apply directly to the pathogenesis of scleroderma only if we knew that the scleroderma B cell is a perfectly normal B cell. There are, however, experimental data pointing to the contrary.

B cells from tight skin mice, an animal model of SSc, exhibit enhanced CD19 signaling and are hyperresponsive. Induced CD19 deficiency in tight skin mice normalizes B-cell responses and attenuates skin fibrosis, while B-cell depletion therapy in such models is effective $[2,3]$. B cells in patients with SSc are present in the skin [4] and the lungs [5]; expression of CD19 is increased and the cells' homeostasis is disturbed [6]. Microarrays from scleroderma skin disclosed fibroblast, endothelial cell and, surprisingly, B-cell genes to be upregulated compared with normal skin [7]. Finally, emerging clinical data suggest a favorable effect of the B-cell depleting agent rituximab on skin and lung fibrosis in patients with SSc [8-10].

How can B cells regulate the fibrotic process? B cells may produce autoantibodies that can either directly stimulate fibroblasts to increase collagen production such as agonistic anti-platelet-derived growth factor receptor autoantibodies [11], or inhibit the function of metalloproteinases and therefore decrease collagen degradation [12]. B cells also produce profibrotic cytokines such as IL-6 or TGF $\beta$. Finally, B cells could directly stimulate fibroblasts via cell-cell contact.
Previous experiments have shown that both B cells in particular and, to a lesser extent, $\mathrm{T}$ cells can bind to cultured fibroblasts in vitro with an as yet unknown functional significance [13]. These are diagrammatically depicted in Figure 1.

This study introduces the novel concept that B cells are profibrotic ex vivo. Several questions remain to be answered. The first question is how B cells physically interact with fibroblasts; this should be explored in future studies. Nevertheless, the most important issue is whether B cells are profibrotic in vivo. The encouraging results of several studies assessing the effect of B-cell depletion in SSc may lead to the hypothesis that B cells are also profibrotic in SSc. The study of Francois and colleagues provides strong experimental evidence in favor of a crucial role of B cells in the pathophysiology of fibrosis and therefore strengthens the rationale of pursuing B-cell targeting therapies in SSc.

\section{Abbreviations}

BAFF: B-cell activating factor; IL: Interleukin; SSc: Systemic sclerosis; TGF $\beta$ : Transforming growth factor beta.

Competing interests

The authors declare that they have no competing interests.

Published: 28 November 2013

\section{References}

1. Francois A, Chatelus E, Wachsmann D, Sibilia J, Bahram S, Alsaleh G, Gottenberg J-E: B lymphocytes and B-cell activating factor promote collagen and profibrotic markers expression by dermal fibroblasts in systemic sclerosis. Arthitis Res Ther 2013, 15:R168.

2. Saito E, Fujimoto M, Hasegawa M, Komura K, Hamaguchi $Y$, Kaburagi $Y$, Nagaoka T, Takehara K, Tedder TF, Sato S: CD19-dependent B lymphocyte signaling thresholds influence skin fibrosis and autoimmunity in the tight-skin mouse. J Clin Invest 2002, 109:1453-1462. 
3. Hasegawa M, Hamaguchi Y, Yanaba K, Bouaziz JD, Uchida J, Fujimoto $M$, Matsushita T, Matsushita Y, Horikawa M, Komura K, Takehara K, Sato S, Tedder TF: B-lymphocyte depletion reduces skin fibrosis and autoimmunity in the tight-skin mouse model for systemic sclerosis. Am J Pathol 2006, 169:954-966.

4. Lafyatis R, Kissin E, York M, Farina G, Viger K, Fritzler MJ, Merkel PA, Simms RW: $B$ cell depletion with rituximab in patients with diffuse cutaneous systemic sclerosis. Arthritis Rheum 2009, 60:578-583.

5. Lafyatis R, O'Hara C, Feghali-Bostwick CA, Matteson E: B cell infiltration in systemic sclerosis-associated interstitial lung disease. Arthritis Rheum 2007, 56:3167-3168.

6. Sato S, Fujimoto M, Hasegawa M, Takehara K: Altered blood B lymphocyte homeostasis in systemic sclerosis: expanded naive B cells and diminished but activated memory B cells. Arthritis Rheum 2004, 50:19181927.

7. Whitfield ML, Finlay DR, Murray JI, Troyanskaya OG, Chi JT, Pergamenschikov A, McCalmont TH, Brown PO, Botstein D, Connolly MK: Systemic and cell type-specific gene expression patterns in scleroderma skin. Proc Natl Acad Sci U S A 2003, 100:12319-12324.

8. Smith V, Van Praet JT, Vandooren B, Van der CB, Naeyaert JM, Decuman S, Elewaut D, De Keyser F: Rituximab in diffuse cutaneous systemic sclerosis: an open-label clinical and histopathological study. Ann Rheum Dis 2010, 69:193-197.

9. Daoussis D, Liossis SN, Tsamandas AC, Kalogeropoulou C, Kazantzi A, Sirinian C, Karampetsou M, Yiannopoulos G, Andonopoulos AP: Experience with rituximab in scleroderma: results from a 1-year, proof-of-principle study. Rheumatology (Oxford) 2010, 49:271-280.

10. Daoussis D, Liossis SN, Tsamandas AC, Kalogeropoulou C, Kazantzi A, Korfiatis P, Yiannopoulos G, Andonopoulos AP: Is there a role for B-cell depletion as therapy for scleroderma? A case report and review of the literature. Semin Arthritis Rheum 2010, 40:127-136.

11. Baroni SS, Santillo M, Bevilacqua F, Luchetti M, Spadoni T, Mancini M, Fraticelli P, Sambo P, Funaro A, Kazlauskas A, Avvedimento EV, Gabrielli A: Stimulatory autoantibodies to the PDGF receptor in systemic sclerosis. N Engl J Med 2006, 354:2667-2676.

12. Sato S, Hayakawa I, Hasegawa M, Fujimoto M, Takehara K: Function blocking autoantibodies against matrix metalloproteinase- 1 in patients with systemic sclerosis. J Invest Dermatol 2003, 120:542-547.

13. Abraham D, Muir H, Olsen I: Adhesion of T and B lymphocytes to fibroblasts in tissue culture. Immunology 1988, 65:385-392.

doi:10.1186/ar4392

Cite this article as: Daoussis and Liossis: B cells tell scleroderma

fibroblasts to produce collagen. Arthritis Research \& Therapy 2013 15:125. 